\title{
“THE FIRST HOSPITAL AMONG CHRISTIANS": THE OSPEDALE DI SANTA MARIA NUOVA IN EARLY SIXTEENTH-CENTURY FLORENCE
}

\author{
by
}

\author{
KATHARINE PARK and JOHN HENDERSON *
}

\begin{abstract}
I make bold to call Santa Maria Nuova the first hospital among Christians. In it they take care of more than three hundred sick people month after month. Difficult as it is to arrange, the beds are always clean and nurses are constantly on duty to look after the sick and see to their needs. Food and medicine are prescribed individually for each patient according to his illness, and physicians and surgeons are always available to give individual instructions. As a result, many rich and noble foreigners have chosen to be treated there when they fall ill during a journey.

Cristoforo Landino, Commentary on the Divine Comedy (c. 1470) ${ }^{1}$
\end{abstract}

The hospitals of the Italian city states were renowned throughout early modern Europe for the quality and efficiency of their service to those in need. Even Martin Luther, no admirer of Roman Catholic institutions, was impressed. "They are splendidly constructed", he acknowledged in the otherwise critical account of Italy written on the occasion of his journey to Rome in 1510-11. "The best food and drink are provided, the attendants are extremely diligent, the physicians learned, the beds and coverings very clean, and the bedsteads painted."2 Luther was only one of the many foreign visitors who commented on the splendours of Italian hospitals and who, as Landino suggested, occasionally sampled those splendours from the inside. Many of the most laudatory accounts appeared in the journals and diaries of English travellers from the sixteenth and seventeenth centuries, including those of Thomas Hoby, Gregory Martin, John Evelyn, Fynes Morison, and Gilbert Burnet. ${ }^{3}$ It is little wonder that when London came to reorganize its charitable corporations in the $1550 \mathrm{~s}$, founding or refounding its hospitals, many of these new institutions closely resembled Italian models. ${ }^{4}$

* Katharine Park, Ph.D., Department of History, Wellesley College, Wellesley, Mass. 02181, USA; John Henderson, Ph.D., Cambridge Group for the History of Population and Social Structure, 27 Trumpington Street, Cambridge CB2 1QA.

All manuscripts referred to in the notes, unless otherwise indicated, are in the Archivio di Stato of Florence.

${ }^{1}$ In Cristoforo Landino, Scritti critici e teorici, ed. Roberto Cardini, vol. 1, Rome, Bulzoni, 1974, p. 116.

${ }^{2}$ Martin Luther, Table talk, in Luther's works, ed. and trans. T. G. Tappert, vol. 54, Philadelphia, Westminster Press, 1967, p. 296.

${ }^{3}$ See E. P. Chaney, "'Philanthropy in Italy": English observations on Italian hospitals, 1545-1789', in

T. Riis, ed., Aspects of poverty in early modern Europe, Stuttgart, Klett-Cotta, 1981, pp. 183-217.

${ }^{4}$ Paul Slack, Poverty and policy in Tudor and Stuart England, London, Longman, 1988, pp. 119-20. 


\section{The Ospedale di Santa Maria Nuova}

London's Savoy Hospital, reportedly established in 1505, is one of the best-known examples of this process. ${ }^{5}$ The initiator of the project was Henry VII, who died in 1509 after allocating a considerable sum toward its construction. It was left to his executors to obtain letters patent from Henry VIII to erect a permanent hospital, completed only in $1517 .^{6}$ The Savoy's model is believed to have been the Florentine hospital of Santa Maria Nuova, as is suggested in the preface to the document translated below. This version of Santa Maria Nuova's statutes-for so they appear to be ${ }^{7}$-was prepared, purportedly at Henry's request, by Francesco Portinari, papal protonotary and member of the Florentine mercantile family that had founded the Italian hospital in the late thirteenth century and retained an important interest in it. The Portinari had close connections to the English court: Francesco's father Tommaso had twice acted as imperial ambassador there, according to a letter sent to Wolsey in 1514 by the Cardinal San Quatuor, while Francesco and his brother Guido had "received liberal favours from the late king, in consideration of their

\footnotetext{
${ }^{5}$ See in general William J. Loftie, Memorials of the Savoy: London, Macmillan, 1878; R. Somerville, The Savoy: manor, hospital, chapel, London, Chancellor and Council of the Duchy of Lancaster, 1960; and H. M. Colvin, D. R. Ransome, and J. Summerson, The history of the King's works, vol. 3, pt. 1 (1485-1660), London, HMSO, 1975, pp. 196-206.

${ }^{6}$ Somerville, op. cit., note 5 above, pp. 9-11, 23-24; J. S. Brewer and R. H. Brodie, Letters and papers foreign and domestic of the reign of Henry VIII, 2nd ed., vol. 1, pt. 1, London, HMSO, 1920, no. 1316.

7 Because this version of the statutes exists only in the two manuscripts prepared as a result of Henry's request (see note 44 below), it is not clear whether they represent the statutes actually governing the hospital at the time or whether they were prepared especially for the occasion by Portinari, to impress his royal patron. The evidence in the text itself in unclear. In his closing letter, Portinari writes of "dividing them up and setting them forth according to our own wit and ability", which could indicate the latter. On the other hand, rubric 34 of the text refers to them as "constitutiones" and provides for their safekeeping and public accessibility, which would suggest the former. Further evidence is their close textual relationship to the only known set of previous statutes, which exist in an Italian summary from 1374 (transcribed in Luigi Passerini, Storia degli stabilimenti di beneficenza e d'istruzione elementare gratuita della città di Firenze, Florence, Le Monnier, 1853, pp. 839-50, from Santa Maria Nuova [SMN]-10, ff. 14v-26v) and which they strongly resemble in form, wording and content. Of the 33 rubrics of the 1374 statute, the majority correspond closely or exactly in their titles and contents to the 34 rubrics of the Portinari document; the main changes involve the order of the provisions and, less often, their internal divisions. (The first half of rubric 2 of the 1374 statute, for example, appears in rubric 2 of the Portinari document, and the second half in rubric 3 , while rubrics 6 and 9 of the 1374 statute have been combined in the new rubric 6.) The main substantive changes concern the rubrics devoted to the care of the sick; in the statute of 1374, this is very briefly and generally specified in rubrics 1 and 30 , while in the Portinari text it has been greatly expanded to occupy rubrics 16 through 23 , which constitute fully a third of the length of the document. The appendix to the Portinari text, concerning various of the hospital's employees, is also new. It may be that the new statutes were produced by Portinari and/or the other governors of the hospital-his use of the first person plural in the closing address to Henry is ambiguous-specifically for the eyes of Henry VII by editing, revising, and updating the previous set, in which case they may or may not have been adopted as the hospital's official constitution. But even if their official status is unclear, we would argue that they represent a generally accurate (if sometimes idealized) account of the operation of Santa Maria Nuova and of the aspirations of its patrons: most of the rubrics regarding the organization and discipline of the hospital are taken almost verbatim from the older statute of 1374 , the validity of which is not in doubt, while the new sections about the care of the sick are not only convincing by the density and specificity of their detail but also corroborated by many other documents in the hospital's archives, as we note below. They also form a consistent trajectory with the description-not in statute form - of the hospital prepared for Ferdinand, King of the Romans, in the mid-sixteenth century (transcribed in Passerini, pp. 867-73, from SMN-10, ff. 32r-38r) and with the later set of regulations from the mid-seventeenth century, reproduced in Giovanni Targioni Tozzetti, Notizie degli aggrandimenti delle scienze fisiche accaduti in Toscana nel corso di anni LX del secolo XVII, vol. 3, Florence, 1780, repr. Bologna, Forni, 1967, pp. $377-422$.
} 


\section{Katharine Park and John Henderson}

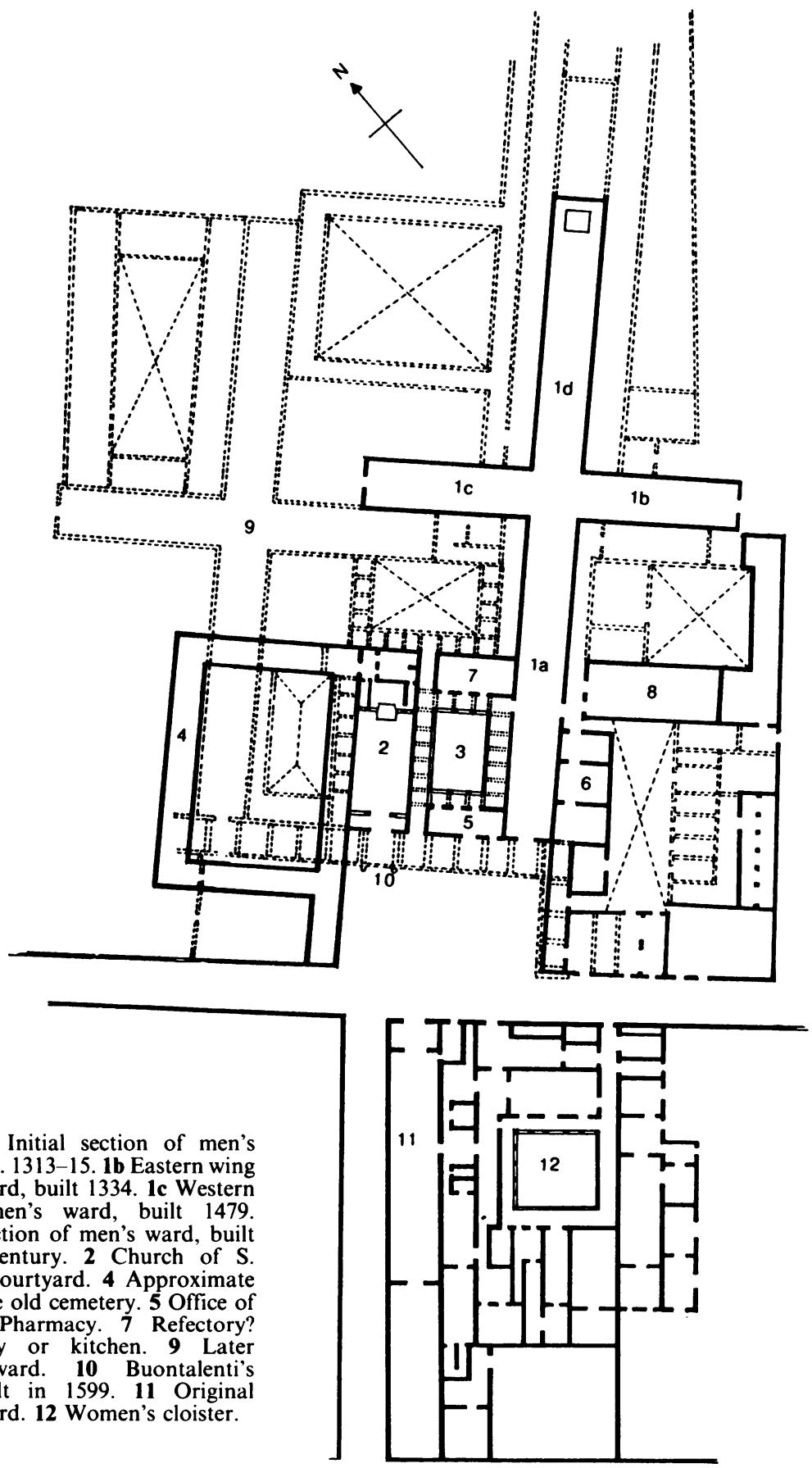

Key: 1a Initial section of men's ward, built $c$. 1313-15. 1b Eastern wing of men's ward, built 1334. 1c Western wing of men's ward, built 1479 . 1d Final section of men's ward, built late 15th century. 2 Church of $S$. Egidio. 3 Courtyard. 4 Approximate extent of the old cemetery. 5 Office of Rector. 6 Pharmacy. 7 Refectory? 8 Refectory or kitchen. 9 Later women's ward. 10 Buontalenti's facade, built in 1599.11 Original women's ward. 12 Women's cloister.

Figure 1. Sketch plan of the Ospedale di Santa Maria Nuova, Florence. Solid lines represent construction as of $c$. 1500, and dotted lines, later additions. Plan drawn by Patrick Sweeney. 


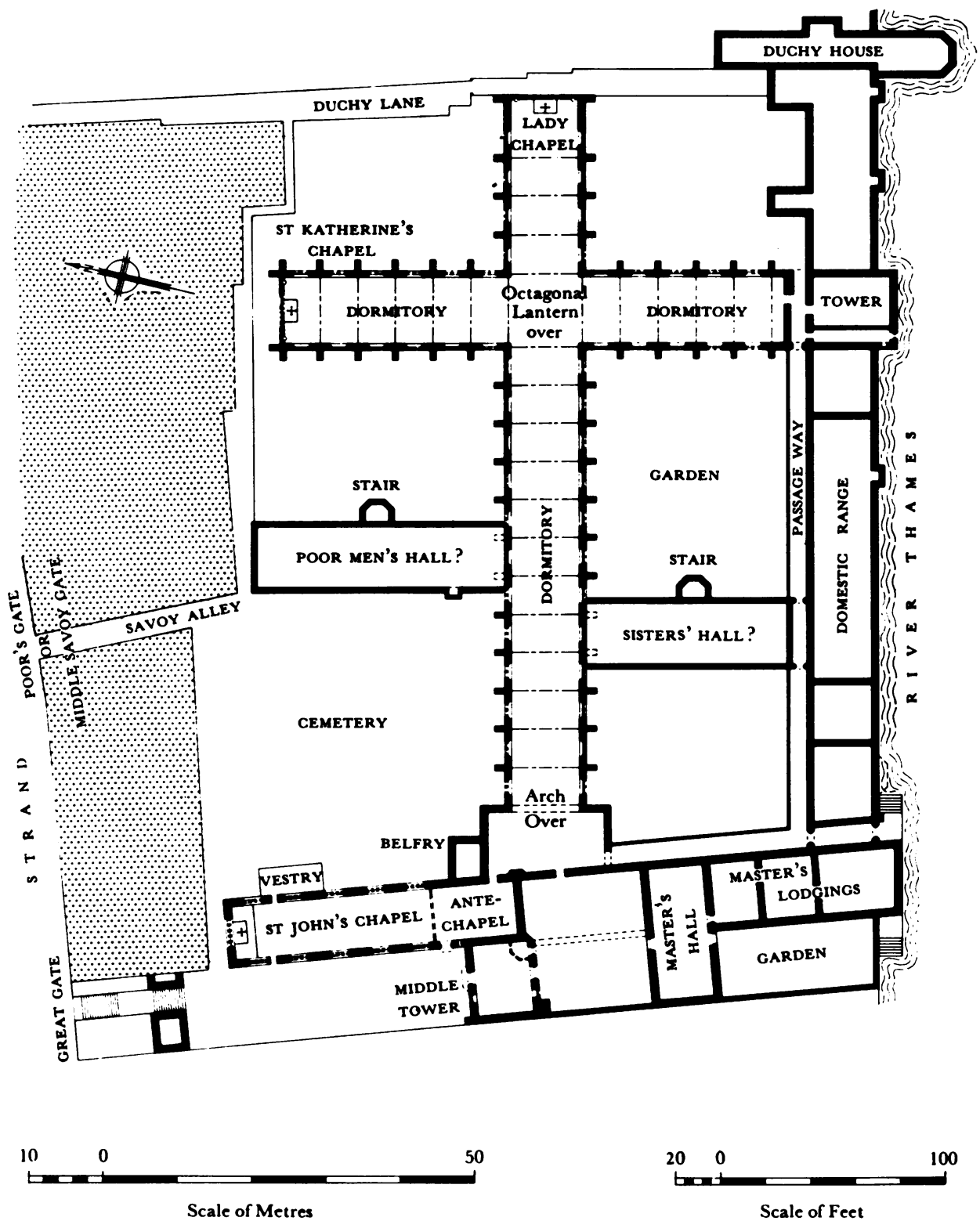

Figure 2. Plan of the Savoy Hospital, from H. Colvin, D. R. Ransome, and J. Summerson, The history of the King's Works, vol. 3 (1485-1660), pt. 1, London, HMSO, 1975. Reproduced by permission of the Controller of Her Majesty's Stationery Office. 


\section{Katharine Park and John Henderson}

father's services". 8 In 1500 , Guido had obtained a royal licence to export three hundred sacks of wool, and he continued to trade in England after Henry VII's death, supplying Italian arms, armour, and luxury cloth to the court. Francesco visited him in 1514; another letter of recommendation from that year refers to a third brother, Giovanni Battista, as rector of St Mary Aldercher (sic), in Wolsey's diocese. ${ }^{9}$

The degree to which the model of Santa Maria Nuova actually influenced the Savoy is still open to question. It seems likely that the Italian hospital inspired its cruciform ground plan, which was uncharacteristic for an English hospital of that period in both form and scale (see figures 1 and 2). ${ }^{10}$ The Savoy's earliest surviving statutes, dated 1523, reveal some parallels to their Florentine counterparts. These include an elaborate division of labour; lavish and detailed specification of the linens on the hospital's hundred beds (the same number as in the men's ward of Santa Maria Nuova); an overriding concern with cleanliness; and special provisions for the care of the sick, who were to be attended twice daily by a doctor and a surgeon, both salaried by the hospital. ${ }^{11}$ In other respects, however, the two sets of statutes differ in emphasis and content. The Savoy appears to have been less communally and more hierarchically organized, and its statutes devote relatively more space to issues of moral and religious discipline and less to medical procedures and record-keeping. It employed many fewer doctors than Santa Maria Nuova, and its pharmacy was much less well developed, relying on the plants grown in its gardens; there is no mention of a resident pharmacist and staff. These differences reflect not only the generally more rudimentary state of English medical organization but also a less specialized charitable mission; whereas Santa Maria Nuova took the sick poor as its unique charge, the Savoy only gave them preference, admitting also (in order of descending priority) the crippled, blind or infirm; "shamefaced poor beggars"; and "all others". 12 The sick were allowed to stay until well, while the others were turned out each morning. Finally, although the Savoy did not admit women, unlike Santa Maria Nuova, it prescribed a much stricter sexual division of labour among its staff, leaving all of the nursing to a matron and twelve "sisters". 13

As impressive as Santa Maria Nuova may have been, it should not be seen in isolation from other Tuscan hospitals of the period. Even in the mid-fifteenth century,

\footnotetext{
${ }^{8}$ Brewer and Brodie, op. cit., note 6 above, vol. 1, pt. 2, no. 3289.

${ }^{9}$ Calendar of the patent rolls preserved in the Public Record Office. Henry VII, vol. 2 (1494-1509), London, HMSO, 1916, p. 234; Brewer and Brodie, op. cit., note 6 above, vol. 1, pt. 2, nos. 3280, 2906, and ad indicem.

${ }^{10}$ Somerville, op. cit., note 5 above, pp. 13-14; and Colvin, Ransome, and Summerson, op. cit., note 5 above, pp. 198-201. For the architectural history of Santa Maria Nuova in this period, see Guido Pampaloni, Lo spedale di Santa Maria Nuova e la costruzione del loggiato di Bernardo Buontalenti, Florence, Cassa di Risparmio, 1961, especially pp. 14-20. We are most grateful to Patrick Sweeney for his advice and also for drawing the plan of Santa Maria Nuova reproduced here. Annotations to the plan are based on Pampaloni, ibid., chapter 1; and Walter and Elizabeth Paatz, Die Kirchen von Florenz: ein kunstgeschichtliches Handbuch, vol. 4, Frankfurt, Vittorio Klostermann, 1952, pp. 1-31.

11 Harvard Law School Library (Cambridge, Massachusetts), MS 11, especially rubrics 31 and 33; note that the Savoy's beds were single, while Santa Maria Nuova's were made for two. On these statutes, see Somerville, op. cit., note 5 above, p. 27; Somerville summarizes a shortened version, in British Library, Cotton MS, Cleopatra C.V, on pp. 28-32, 250-1.

12 Harvard Law School Library, MS 11, rubric 32.

13 Ibid., rubrics 27-9; in Santa Maria Nuova, male nurses looked after the sick in the men's ward.
} 


\section{The Ospedale di Santa Maria Nuova}

according to the contemporary humanist and architect Leon Battista Alberti, Tuscany was famous for its "tradition of religious piety", boasting "splendid hospitals, built at vast expense, where foreigners as well as natives receive everything they need for treatment". ${ }^{14}$ The rulers of various northern Italian states, such as the Sforza in Milan, looked to Tuscany when building hospitals, and they owed their inspiration to both Santa Maria Nuova and the great hospital of Santa Maria della Scala in Siena. Like Henry VII, they were impressed not only by the size and administration of these two hospitals, but also by their architectural design. ${ }^{15}$

Unique to Santa Maria Nuova, however, was its unrivalled reputation as a medical centre. When Landino described it as "the first hospital among Christians", he claimed only that it was the most outstanding charitable institution of its kind. But his statement is true in another way: Santa Maria Nuova was arguably the first Western European hospital in the modern sense of the word, an institution organized along therapeutic lines and dedicated exclusively to the care of the sick, which was directed by lay members of the medical profession. Hospitals of this sort had existed in many medieval Islamic and Byzantine cities, but Santa Maria Nuova represents the earliest example of such an institution in western Christendom. ${ }^{16}$ Like its Muslim and Byzantine predecessors, it was in conception and organization as much a religious as a medical institution, governed by a constitution and regulations that were clearly religious in tone. As the statutes translated below show, as early as 1500 , it incorporated into this constitution many aspects of hospital life usually identified as inventions of the eighteenth century. Still one of the principal hospitals in Florence, Santa Maria Nuova is the oldest direct ancestor of the hospitals we know today. ${ }^{17}$

Santa Maria Nuova's emergence as a specialized medical institution was part of the general history of both philanthropy and medicine in the later Middle Ages and Renaissance. The period from 1300 to 1500 saw a gradual shift in the emphasis of charity away from the earlier medieval concept of generalized "hospitality" to the needy, toward the provision of poor relief for the indigent-a process also underway in the somewhat later statutes of the Savoy. In Florence, particularly after the Black Death of 1348, we see a gradual specialization among the larger charitable institutions. The initial beneficiaries included widows and orphans-biblically sanctioned and legally impotent-as well as, increasingly, the sick poor. ${ }^{18}$ Santa Maria Nuova also reflected the general flowering of medical institutions in the Italian

\footnotetext{
${ }^{14}$ Leon Battista Alberti, L'architettura (De re aedificatoria), ed. and trans. G. Orlandi and P. Portoghesi, vol. 1, Milan, Il Polifilo, 1966, pp. 367-8.

${ }^{15}$ See John Henderson, 'The hospitals of late medieval and Renaissance Florence: a preliminary survey', in Lindsay Granshaw and Roy Porter, eds., The hospital in history, London, Routledge, 1989, pp. 74-6.

${ }^{16}$ See Michael W. Dols, 'The origins of the Islamic hospital: myth and reality', Bull. Hist. Med., 1987, 61: 367-90; Sami Hamarneh, 'Development of hospitals in Islam', J. Hist. Med., 1962, 17: 366-84; Timothy S. Miller, The birth of the hospital in the Byzantine Empire, Baltimore, Johns Hopkins University Press, 1985.

${ }^{17}$ See, for example, Michel Foucault, The birth of the clinic: an archeology of medical perception, trans. A. M. Sheridan Smith, New York, Vintage Books, 1975, especially the introduction and chapters 1 and 5.

${ }^{18} \mathrm{See}$ in general Henderson, op. cit., note 15 above; idem, Piety and charity in late-medieval Florence, Oxford University Press, 1992, chs. 7-9; and Katherine Park, 'Healing the poor: hospitals and medicine in Renaissance Florence', in Jonathan Barry and Colin Jones, eds., Medicine and charity, London, Routledge, 1991.
} 


\section{Katharine Park and John Henderson}

city-states of the late Middle Ages and Renaissance. ${ }^{19}$ Some of these institutions, such as the municipal colleges of physicians, embodied efforts by medical practitioners to defend their economic interests and their intellectual and social status. Others represented lay attempts to solve, or at least to alleviate, pressing problems of public health. These problems posed themselves with special intensity in the fourteenth and fifteenth centuries, as a series of epidemics-including but not restricted to plagueswept through Italian cities. In their attempts to control the spread of disease, Italian authorities experimented with various measures, which included the establishment of permanent health boards to coordinate and implement public health provisions, municipal bills of mortality to record all deaths in a city, systems for isolating and quarantining plague victims, and the employment of public doctors for the poor. ${ }^{20}$

The nature and emphasis of these initiatives varied according to both time and place, as medieval Italy was divided into numerous city-states, each fiercely independent from its neighbour. Venice, for example, invested heavily in municipally salaried doctors, while Milan and the Lombard towns moved toward more coercive public health measures directed at infected or potentially infected groups, who were interned in general institutions together with the homeless, the aged, widows, and orphans. ${ }^{21}$ But perhaps the most important product of this period of experimentation was the large, specialized hospital for the sick poor. Tuscany in general, and Florence in particular, were at the forefront of these developments, and Florence's specialized medical hospitals, of which Santa Maria Nuova was the prototype, quickly became the objects of interest and admiration. As Landino indicated, by the late fifteenth century Santa Maria Nuova was recognized as exemplary, even in the sophisticated institutional world of northern and central Italy. ${ }^{22}$

The internal organization of Santa Maria Nuova as it appears in the statutes sent to Henry VII was the product of a long process of evolution. The hospital's origins were humble. Founded by Folco di Ricovero Portinari, a Florentine merchant and patrician, and father of Dante's Beatrice, it opened its doors in 1288 on the site of the former convent of Sant'Egidio, just outside the old city walls. Santa Maria Nuova's history reflects the more general shift in charity described above, for Portinari defined

\footnotetext{
${ }^{19}$ For a general idea of these institutions, see Katharine Park, Doctors and medicine in early Renaissance Florence, Princeton University Press, 1985, especially chapters 1 and 3; Carlo M. Cipolla, Public health and the medical profession in the Renaissance, Cambridge University Press, 1976; and Irma Naso, Medici e strutture sanitarie nella società tardo-medievale: il Piemonte dei secoli XIV e XV, Milan, Franco Angeli, 1982.

${ }^{20}$ Details in Cipolla, op. cit., note 19 above; Naso, op. cit., note 19 above, chapters 1-3; Ann G. Carmichael, Plague and the poor in Renaissance Florence, Cambridge University Press, 1986; John Henderson, 'Epidemics in Renaissance Florence: medical theory and government response', in N. Bulst and R. Delort, eds., Maladies et société (XIIe-XVIIIe siècles), Paris, CNRS, 1988; Richard Palmer, 'Physicians and the state in post-medieval Italy', in Andrew W. Russell, ed., The town and state physician in Europe from the Middle Ages to the Enlightenment, Wolfenbüttel, Herzog August Bibliothek, 1981, p. 47; Vivian Nutton, 'Continuity or rediscovery? The city physician in classical antiquity and medieval Italy', in ibid., pp. 26-9.

${ }^{21}$ On Venice, see Bartolomeo Cecchetti, 'La medicina in Venezia nel 1300', Archivio veneto, first series, 1883, 26: 85-8. On Milan, Giuliana Albini, Guerra, fame, peste: crisi di mortalità e sistema sanitario nella Lombardia tardomedievale, Bologna, 1982, chapter 2.

22 Brian Pullan, Rich and poor in Renaissance Venice: the social institutions of a Catholic state to 1620, Cambridge, Mass., Harvard University Press, 1971, pp. 205-6; Henderson, op. cit., note 15 above, pp. 74-6.
} 


\section{The Ospedale di Santa Maria Nuova}

its functions as providing for any pauper who fell within the general category of the "Poor of Christ". At the beginning it accommodated only seventeen beds, five probably reserved for the staff and twelve in the single dormitory for the "poor and sick" men and women it was established to shelter. ${ }^{23}$

Over the next two centuries, it underwent an impressive series of transformations. In the first place, it expanded dramatically, both physically and financially. A separate male infirmary was built in 1313, and by 1376 the hospital had 62 double beds for sick men and 58 for sick women. By the early sixteenth century, there were 100 beds in the men's ward, a number equal or close to that in the women's ward, and about 50 more in other, smaller rooms. The hospital received an average of about 3,000 male patients a year-from the less complete records of the women's wing it is impossible to determine the precise number of female patients - and claimed a total of 500 dependents. $^{24}$ This expansion was made possible by the increasing volume of bequests and public subsidies received by the hospital. Santa Maria Nuova's financial status in early sixteenth-century Florence found expression in the chronicler Benedetto Varchi's somewhat exaggerated claim that it would have owned "most of Florence, if the Heads of the hospital had not from time to time sold some of its possessions to support its activities ...".25

Santa Maria Nuova's growth went hand in hand with its emergence as a specialized medical institution whose charitable activities focused exclusively on the sick. We can trace this development in the successive descriptions and statutes of the hospital as well as in the internal financial and administrative documents that reflect its changing policies. ${ }^{26}$ By the early 1320 s, the hospital aimed to succour the "sick poor", rather than the "sick and the poor", while the statute of 1374 restricted the stay of any healthy guest to three days and an inventory of 1376 reveals a splendidly equipped pharmacy. ${ }^{27}$ The increasingly medical character of the hospital was reflected in the expansion of its professional medical personnel: it employed two doctors (a physician and a surgeon) for most of the fourteenth century, three in the early fifteenth, four in 1450 , and ten by the time of the letter to Henry VII. ${ }^{28}$

\footnotetext{
${ }^{23}$ See the document relating to the initial foundation and the opening inventory: Santa Maria Nuova-1 (hereafter SMN-1), document of 23.vi.1288; and SMN-10, ff. 1r-2r. Brief accounts of the early history of Santa Maria Nuova appear in Pampaloni, op. cit., note 10 above, chapter 1; Ottavio Andreucci, Della carità ospitaliera in Toscana: studi documentati e proposte . . , vol. 1, Florence, Bencini, 1864, pp. 9-28; and Passerini, op. cit., note 7 above, pp. 284-395, 839-92.

${ }^{24}$ Luigi Chiappelli and Andrea Corsini, 'Un antico inventario dello spedale di Santa Maria Nuova in Firenze (a. 1376)', Rivista delle biblioteche e degli archivi, 1921, 32: 12, 36 (items 203, 1122); SMN-4, f. 50r. For the physical structure of the hospital, see Pampaloni, op. cit., note 10 above, pp. 14-20 and chapter 2. Figures for admissions are based on the "books of the dead" of the male ward for the period in question: SMN-731. The number of dependents comes from the 1527 Florentine census, in Biblioteca Nazionale Centrale di Firenze: N.A. 987, f. 92v.

${ }^{25}$ Benedetto Varchi, Storia fiorentina, ed. Lelio Arbib, vol. 2, Florence, 1840, p. 100: according to the hospital's accounts, its expenditures in the early sixteenth century amounted to about 15,000 gold florins a year (SMN-4526, ff. 94v-95r).

${ }^{26}$ References in note 7 above.

${ }^{27}$ SMN-1, f.1r; Passerini, op. cit., note 7 above, p. 843; Chiappelli and Corsini, op. cit., note 24 above, items $249-553$.

${ }^{28}$ Statement based on a selection of the hospital's account books, including SMN $4408,4437,4453,4458$, 4477,4479 , and 4495 , as well as the statute translated below.
} 


\section{Katharine Park and John Henderson}

The elaboration of Santa Maria Nuova's medical organization was gradual. Thus it is difficult to attribute it to the vision of a single individual, although several of the hospital's rectors presided over periods of particularly significant change. These included Lorenzo di Iacopino da Bibbiena (rector 1308-32), Orlando di Pierozzo da San Casciano (1332-48), and Benino Benini (1477-85), all of whom oversaw important building programmes, as well as Leonardo Buonafè (1500-27), who reformed the hospital's finances and expanded and reorganized its medical facilities. ${ }^{29}$ It is equally difficult to argue for any direct influence from Eastern models, despite striking parallels with the medical organization and practice of medieval Islamic and Byzantine hospitals: Greek emigrés such as John Argyropoulos, who practised at the Pantocrator in Constantinople, may well have brought useful information about the operation of Eastern hospitals to Florence in the mid-fifteenth century, but the medical character of Santa Maria Nuova was already well established by that time. ${ }^{30}$ Thus the institution, at least in its general outlines, seems overwhelmingly an indigenous and collective creation, the product of local conditions and several centuries of collaboration among its administrators, patients, and staff.

All of these changes find expression in the statutes sent to Henry VII, particularly the rubrics dealing with the care of the sick. These show that, by the early sixteenth century Santa Maria Nuova saw its charitable role in specifically medical terms, as the nursing and healing of the sick. It had developed an elaborate organization and highly formalized bureaucratic procedures that allowed it to provide individualized care to hundreds of patients at a time, and it offered a wide range of medical services-also without charge-to the inhabitants of Florence and its surrounding countryside, both rich and poor.

The hospital continued to devote most of its medical resources to receiving and treating humbler patients in its men's and women's infirmaries. At the same time, it maintained a special small ward for priests and clerics and eight private rooms "reserved for the sick of higher social class", in the words of rubric 21 of the statutes, travellers and local residents who had chosen to enter the hospital on account of either poverty or piety. (Sixtus IV had granted a plenary indulgence to the hospital's patients as well as to its staff and benefactors.) ${ }^{31}$ Santa Maria Nuova also sponsored a surgical clinic, the medicinarium, for the use not only of those in the wards but also of outpatients suffering from "sores and other minor illnesses". In addition, the hospital sent its trained nurses to private houses throughout the city to treat the seriously ill, "including nobles and patricians". It acted as a public dispensary for both medicines and medical advice, and it supervised Florence's lazzaretto, San Bastiano, built in the late fifteenth century to isolate and treat victims of plague. ${ }^{32}$ And it had functioned as a medical library for over a hundred years, lending books and manuscripts to local surgeons and physicians. ${ }^{33}$

\footnotetext{
${ }^{29}$ See SMN-1 for a full chronological list of the rectors of the hospital.

${ }^{30}$ Miller, op. cit., note 16 above, pp. 158, 196, 206.

${ }^{31} \mathrm{SMN}-10$, f. $12 \mathrm{v}$.

${ }^{32}$ See Henderson, op. cit., note 20 above; A. Corsini, La 'moria' del 1464 in Toscana e l'istituzione dei primi lazzaretti in Firenze ed in Pisa, Florence, 1911.

${ }^{33}$ See SMN-31, ff. 4r, 6r.
} 


\section{The Ospedale di Santa Maria Nuova}

As the statutes indicate, the administrators of Santa Maria Nuova were committed to provide its patients with the best medical treatment they could afford, according to the highest standards of contemporary practice. By 1500 , they had ten doctors to supervise the medicinarium and the men's infirmary: three junior residents, six senior physicians, and a surgeon. The first worked for room and board, and the latter, identified as "the best in the city", apparently volunteered their services. Several empirically trained practitioners drawn from the lay brothers and sisters assisted the last and took full responsibility for the women's infirmary. (In this period, both male and female empirics were legitimate and often highly respected members of the medical profession.) ${ }^{34}$

As Landino indicated, the hospital went to great lengths to adapt each patient's care to his or her special needs. In addition to the main wards, it maintained two special rooms, one an intensive care facility for those with serious wounds and another to restrain the violently insane. To this end, the infirmarers had developed a system based on a meticulous division of labour and elaborate record-keeping; they assigned each patient to one of the resident doctors, who followed the course of his or her illness. The sick were visited frequently. Each day they received new prescriptions, ordered by the hospital's doctors, compounded by its pharmacist and his four apprentices, and identified for efficiency and accuracy by the number of the patient's bed. The treatments described in the regulations-medication, minor surgery, compresses, plasters, enemas, and the like-represent standard medical procedure for the period. The same can be said for the emphasis on the individual regulation of what was called "diet": food and drink (with a heavy emphasis on chicken broth), air, exercise, sleep, and the regulation of the emotions. The "six non-naturals", as these were known, formed an important branch of medical treatment in the Middle Ages and Renaissance - $a$ fact that renders anachronistic any clear distinction between care and cure. ${ }^{35}$

It is of course dangerous to assume that the ideal order presented in this document corresponded in every detail to actual practice, even assuming, as we have argued, that it represents a genuine set of statutes. ${ }^{36}$ (As the cringing tone of Francesco's preface and postscript indicates, his aim was not only to provide useful information but also to impress the King with the merits of his family and his city.) We cannot know, for example, whether the hospital's physicians were conscientious in fulfilling their duties or whether the surgeon spent his prescribed four hours in the medicinarium each day. But other records confirm many aspects of the early sixteenth-century regulations. The treasurer's account books, kept in meticulous detail, show large annual expenditures on charcoal, linens and ashes "for the

\footnotetext{
${ }^{34}$ Until the middle of the fifteenth century, the doctors had been regular employees of the hospital, drawing an annual salary. For details on this and on empirical practice in Florence, see Park, op. cit., note 19 above, pp. 66-72 and 104-5.

${ }^{35}$ For an introduction to medieval medical theory and therapeutics, see Nancy G. Siraisi, Taddeo Alderotti and his pupils: two generations of Italian medical learning, Princeton University Press, 1981, esp. chapter 5 and pp. 290-302; on diet, ibid., p. 137 and references in her note 46. Also idem, Medieval and early Renaissance medicine: an introduction to knowledge and practice. University of Chicago Press, 1990, chapter 5 .

${ }^{36}$ See note 7 above.
} 


\section{Katharine Park and John Henderson}

laundry", as well as wine, fruit and vegetables "for the sick", the poultry that went into the hospital's famous chicken broth and the pureed chicken that formed the backbone of its therapeutic regimen, and almost 30,000 eggs a year. The same books itemize supplies purchased for the hospital's pharmacy and infirmaries: leeches, lancets, scissors, and cloth for bandages, a vast range of common herbal ingredients and standard medicinal compounds, as well as a number of such exotic and expensive items as preserved ginger from Venice, gold leaf, precious stones, water imported from distant springs, and even an occasional exorbitantly-priced shipment of opium. ${ }^{37}$

We can fill in more details about the medical treatment offered at Santa Maria Nuova in the early sixteenth century from a notebook of hundreds of medical recipes "tried and tested ... in Santa Maria Nuova" and compiled in 1515, apparently by one of its doctors. This notebook has nothing in common with the popular medical collections of the period, with their simple formulas and heavy reliance on prayers and incantations. It reflects rather the most up-to-date professional practice. ${ }^{38} \mathrm{With}$ the exception of a single remedy for impotence, its remedies were entirely naturalistic and often quite complicated. They covered a vast range of medical and surgical conditions, from insomnia to skull fractures, from dysmenorrhoea to hernias, and they were drawn from many different sources, including well known medical texts (Mesue, Haly Abbas, Rhazes' Liber ad Almansorem) and past and present doctors of Santa Maria Nuova and San Paolo, the other major Florentine hospital for the sick. These local physicians were always identified by name; they included many wellknown practitioners-Agostino di Stefano Santucci and Piero di maestro Domenico dal Pozzo Toscanelli, among others-as well as Monna Francesca and Monna Caterina, "house doctors", who were evidently the women referred to with such respect in rubric 29 of the ordinances translated below. ${ }^{39}$ A number of the remedies even seem to have been formulated for a particular patient, like the "woman whose mouth hurt because it was full of sores". 40

In terms of organization and intention, then, Santa Maria Nuova was well established as a specialized medical institution by the early sixteenth century. The hundred and fifty years that followed saw several important innovations in its relation to the medical profession-the integration of hospital practice into the licensing requirements of the Florentine Guild of Doctors, for example, and the creation in the late sixteenth century of a formal school of surgery on the premises-but little fundamental change in the hospital's internal operations and organization. ${ }^{41}$ It is difficult to argue from impressive organization to therapeutic

\footnotetext{
${ }^{37}$ See e.g. SMN-5085 (quaderno di cassa, 1504-6); 4526 (uscita, 1504-6).

38 Biblioteca Nazionale Centrale di Firenze: MS Magl. XV, 92, ff. 27r-192r. Cf. [Ruberto di Guido Bernardi], Una curiosa raccolta di segreti et di pratiche superstiziose fatta da un popolano fiorentino del secolo $X I V$, ed. Giovanni Giannini, Città di Castello, S. Lapi, 1898; references to other, similar works in ibid., p. 6.

${ }^{39}$ Agostino di Stefano Santucci had a considerable academic reputation, and his elaborate tomb is still visible in the central aisle of Santa Croce. Piero di Domenico Toscanelli, brother of the humanist and mathematician Paolo, was perhaps the richest physician in Florence.

${ }_{40}$ Biblioteca Nazionale Centrale di Firenze: MS Magl. XV, 92, f. 55r.

41 See Enrico Coturri, 'La scuola di Santa Maria Nuova di Firenze', Ospedali d'Italia, Chirurgia, 1964, 10: 379-83; and idem, 'Le scuole ospedaliere di chirurgia del Granducato di Toscana (secc. XVII-IX)', Minerva
} 
effectiveness. We know even less about the experience of Santa Maria Nuova's patients than that of its doctors and nurses, and it is clear that conditions in the wards deteriorated in times of epidemic, famine, and war. We do, however, possess one striking body of evidence for the hospital's ability to heal the sick: the "books of the dead" described near the beginning of rubric 21 . These remarkable records identify each patient not only by name, place of origin, and bed, but also, in the case of male patients, admission number, which allows us to determine how many men were received in the infirmary each year, as well as how many died. These indicate a discharge rate in the decade from 1505 to 1514 that varied between 86 and 91 per cent. $^{42}$

Under these circumstances, it is easy to understand why English travellers were so impressed by what they saw in the hospital of Santa Maria Nuova, and why Henry VII would have requested a copy of its regulations when he began to think about founding a hospital of his own. In the end, the Savoy Hospital turned out to be a different and more traditional hospital than its Florentine prototype. But the example of Santa Maria Nuova may not have been entirely without influence on English models. We find what could be a distant echo of it in the works of one of the most prominent statesmen in Henry VII's court, Sir Thomas More. The exotic island society described in his Utopia boasted many strange and admirable institutions, not the least of which were its hospitals:

These are so roomy as to be comparable to as many small towns ... . [They] are very well furnished and equipped with everything conducive to health. Besides, such tender and careful treatment and such constant attendance of expert physicians are provided that, though no one is sent to them against his will, there is hardly anybody in the whole city who, when suffering from illness, does not prefer to be nursed there rather than at home. ${ }^{43}$

\section{The Text of Francesco Portinari's letter to Henry ViI, incorporating statutes for Santa Maria NuOva (c. 1500) ${ }^{44}$}

To Henry VII, most illustrious, glorious, and invincible king of England and France and lord of Ireland, Francesco Portinari, papal protonotary, wishes happiness and success.

There are three types of good things, most glorious king, and we shall call that man completely happy and fortunate and shall believe the heavens wholly propitious to him in whom all of these goods coincide: smiling fortune, a healthy body, and shining virtue. Among

medica, Nov. 1958, 49: 32-7. The main internal changes were the increase in the number of surgeons practising in the medicinarium from one to six, and the creation of two special wards in the women's infirmary for prostitutes and young girls; see the mid-seventeenth-century regulations edited in Targioni Tozzetti, op. cit., note 7 above, pp. 383 and 405 .

42 Based on the entries in SMN-731 and 733; the number of patients admitted per year ranged between c. 2,350 and c. 4,700. For a detailed discussion of these figures, see Park, op. cit., note 18 above.

${ }^{43}$ More, Utopia, trans. G. C. Richards, in The complete works of St. Thomas More, vol. 4, ed. Edward Surtz and J. H. Hexter, New Haven, Yale University Press, 1964, pp. 139-41.

44 The following translation is based on a collation of Bodleian MS 488, which is probably the presentation copy produced for Henry VII, and BL Additional MS. 40077, which may be one of the hospital's copies. Both are illuminated manuscripts of the early sixteenth century, apparently produced in Florence, and their texts are virtually identical. Professor de la Mare has attributed the illuminated border 


\section{Katharine Park and John Henderson}

men of this sort, who are extremely rare, if they exist at all - but then all admirable things are rare-you must be counted in the first rank by the greatness of your majesty and serenity, indeed as someone in whom all of these types of good fortune are present to perfection. But those higher goods of body and fortune are subject not so much to our will as to the accidents of fate, as Cicero so felicitously says. To cultivate the virtues of the mind, to embrace them, to engage in them-in truth, that must be considered wisdom and the treasury of prudence. For there is an infinite distance between man and God, which distance only virtue can truly span, through which alone mortals can attain immortality.

Truly you, most humane of all kings who have been, are and will be, have become a heavenly hero through the practice of all virtues, so that you can justly and deservedly be called Divine Henry, in the Roman style. Whence it happens, that drawn by the greatness of your power and the piety of your majesty - by which piety alone we approach God, the fulfilment of whose law is love-you are preparing to found a place of residence and succour for the sick. For that reason your most illustrious lordship has asked that we commit to paper the constitution, statute and organization of our great and splendid hospital. Which thing we have done all the more willingly, because our city has gained thereby a welcome lustre and because we felt bound to gratify you, most generous of kings, since we are devoted to your most excellent crown.

Therefore, most gentle king, accept with a smiling visage that which you have requested, which will be the more welcome to us, on account of our exertions, the more gladly your serenity accepts it. Farewell, perpetually happy one.

In the name of the supercelestial and glorious God, and of Mary, mother of God and perpetual virgin, here begins the account of the founding, constitution, and practice of the great hospital of Santa Maria Nuova in the city of Florence.

Folco di Ricovero Portinari, a Florentine citizen, founded the hospital in June 1278 [actually 1288; Bodleian MS has 1284], to the honour and glory of God and of His mother Mary.

[1] How the Rector of the hospital is chosen.

The governors and patrons of the hospital are the descendants of Folco Portinari through the male line, and they elect the Rector of the hospital [hospitalarius], when the position falls vacant, by a two-thirds majority of those present. The vote is taken using white and black beans, in the Florentine manner. ${ }^{45}$ The Rector is always a religious, at least forty years old, of good reputation and excellent character. A record of this election is drawn up by a public notary and confirmed in the usual way.

[2] How the Rector of the hospital and its family should live.

First, we order the Rector of the hospital, its officers, its lay brothers [conversi], and all the other members of its household to live together in piety for the salvation of their souls and the good of the hospital, bearing each other's troubles, grievances, and ignorance. They shelter and tend the sick poor who come to the hospital as they would Christ Himself. They must receive them with their own hands, care for them, console them, and warm, feed, and wash them with compassion. They must attend to their needs and treat them with all care and charity. We wish

of the former to the Florentine illuminator Vante degli Attavanti, known as Attavante, and she has identified the scribe as possibly Alessandro da Verrazzano. See Professor de la Mare's unpublished notes on the manuscript for the exhibition of Italian manuscripts at the Bodleian. We are grateful to Professor de la Mare for permission to quote from her notes. Cf. also F. Saxl and R. Wittkower, British art and the Mediterranean, London, Oxford University Press, 1948, pl. 36, no. 4. On Attavante see A. Garzelli, Miniatura fiorentina del rinascimento, 1440-1525: un primo censimento, Florence, 1985, vol. 1, pp. $219-37$. The transcription of the Latin text in Passerini, op. cit., note 7 above, pp. 851-67 is apparently based on a manuscript transcription made in the eighteenth century by Giovanni Targioni Tozzetti; besides being misdated (to 1524), it includes numerous minor errors and several major ones, including the substitution of Henry VIII for Henry VII in the prefatory letter.

${ }^{45}$ See Nicolai Rubinstein, The government of Florence under the Medici, 1434-94, Oxford, Clarendon Press, 1966, chapter 1 . 


\section{The Ospedale di Santa Maria Nuova}

the Rector to appoint nurses and attendants for both the men's and the women's wards to look after the sick day and night, encourage them with charity, and see to all their needs.

Since the Rector is the leader and guide of his family, he must be of irreproachable life, holy and upright in his actions and manner, so that he can serve as a model of virtue and an example to the others. Thus we have decided that he, along with the other officers and members of the hospital's household, should wear a simple habit of coarse and inexpensive grey cloth marked with the seal of the hospital, a crutch cut from red or green cloth; the Rector should bear this symbol on the left side, the others, on the right.

[3] The Rector may hold no other benefices. Furthermore, neither he nor any member of the hospital family may hold any property.

The Rector of the hospital may not hold, manage or occupy any other position or benefice except that of the hospital. If he does so at the time of his election he must renounce it within three months and so notify the archbishop of the city and the patrons and governors of the hospital; otherwise the election is null and void. The same goes for the lay brothers, perpetual servants [servi perpetuales], and other members of the hospital's household. ${ }^{46}$ The Rector may possess no private property of any kind, either money or land. If he owns or has exclusive use of any such property at the time of his election, he must publicly renounce it within three months and transfer it to the hospital, where it will go to support the sick poor, and he must so notify the patrons and governors of the hospital, or the majority of them present in Florence at the time. If he does not, his election and appointment are void, the Rectorship is understood to be vacant, and the patrons can and should hold a new election. The same applies to the lay brothers, perpetual servants, and other members of the hospital household, both male and female.

[4] Rights and authority of the Rector of the hospital.

The Rector elected by the patrons administers and oversees both the men's and the women's hospitals. He has full authority to appoint and dismiss both male and female members of the staff and the perpetual servants in the hospital's interest. He has the right to hire officials and healers to administer the care of the sick poor as described below. He also has the power to buy and sell property on behalf of the hospital and to do anything in its manifest interest. He has papal authority to alienate the hospital's property. ${ }^{47}$

[5] All owe obedience to the Rector.

Furthermore, we have decided that all lay brothers, perpetual servants, and all those under the hospital's jurisdiction, both male and female, must do as they are asked by the Rector of the hospital or by the other officials under whom they work. They must obey them in all matters, diligently and piously, subject to the penalties contained in the chapters of this constitution.

\footnotetext{
46 The main residents and staff of the hospital were the conversi, or lay brothers, and the servi and servae, or "servants". The former exercised greater authority within the hospital and acted as advisors to the Rector, as specified by a number of provisions in this text. As early as 1324, the number of conversi was set at six, to be replaced as each retired or died: see SMN-9, f. 23r; SMN-10, ff. 4r-v, 6r. The servants were of lesser status and performed the more menial tasks. There seem to have been two types of servants: "perpetual", who had given all their property to the hospital and committed themselves to a lifetime of residence and service within its walls, and non-perpetual, who had made a temporary commitment to the hospital. A document from the early fourteenth century refers also to lay sisters (converse), "who will take care of the sick women" (SMN-1, ad annum $1313 \mathrm{ff}$.), but that office seems to have been replaced by the middle of the fourteenth century by the more humble designation of servant (serva), as the hospital expanded and the male conversi were given increasing responsibility for its governance.

${ }^{47}$ The Rector had this privilege from the pope at least as early as 1371 , and it was confirmed by both Nicholas V and Sixtus IV: SMN-4, f. 34r, SMN-9, f. 46r; SMN-10, f. 27r. But there are earlier references to a communal privilege of this sort granted by the governing councils of Florence in 1330 and confirmed in 1348: $S M N-10$, ff. $26 v-27 r$.
} 


\section{Katharine Park and John Henderson}

[6] Election of the treasurer.

The Rector of the hospital, together with the lay brothers or with four of the oldest and most respected men among the perpetual servants and other members of the household, must choose a worthy and appropriate lay brother or perpetual servant to be the treasurer or bursar. Failing this, they must choose one of the temporary lay brothers. The treasurer's term of office is one year. They may confirm him for another year within eight days of the expiry of his office; if they have not done so within those eight days, then his term is over.

Furthermore, within a month of his election the treasurer must take an inventory of all the property and possessions of the hospital, moveable and immoveable, pertaining not only to his own office, but also to the hospital church and to any other official or member of the hospital staff. All this property is committed to the treasurer's care. He must make this inventory and present it within a month of his election, as noted above, to the Rector of the hospital and to its lay brothers, perpetual servants, officials, and other members of the household; he must also notify the patrons and governors, so that they may also attend if they wish. At the end of his term, he must render the property and account for it to the new treasurer, as the Rector of the hospital orders. The infirmarer and steward must do the same for the property that concerns them, together with the other officials in both the men's and the women's hospitals.

\section{[7] The treasurer must record income and expenditures.}

The treasurer must carefully and diligently record in his books everything-money, payments in kind, immoveable property - that he receives in the course of his term. He must record these things clearly and distinctly under the rubrics described below, noting both the names and surnames of the people from whom he receives them, the number of people, the nature of the goods, and the date received, so that it is always clear whence, when, and from whom they have come and in what they consist.

1) Under one heading he should record all income from testaments, bequests, codicils, and any kind of will.

2) Under another heading he should record all alms given personally to the hospital and all offerings to the church and its altars and to the alms-boxes [ceppi] connected with the hospital.

3) Under a third heading let him record all rents received from tenants who hold houses and property from the hospital and the produce received from its farms.

4) Under a fourth heading he should record income from furniture and other possessions sold by the hospital. ${ }^{48}$

[8] The treasurer must record expenditures in the public book of the hospital.

1) Under one heading let him note all payments for grain, bread, wine, wine casks, and everything else required by the steward, or cellarer, and the under-steward, as well as for wax candles.

2) Under a second let him note payments for cheese, fish, oil, salt, meat, lard and fat, poultry, and whatever else pertains to food.

3) Under a third let him record payments for wood, charcoal, ashes, fruit, vegetables, and other things bought retail for the use of the kitchen or garden.

4) Under a fourth let him note all payments for sugar and dried fruit, herbs and spices, wax and medicines, and other things for the sick and for use in the infirmary.

5) Under a fifth heading let the treasurer record payments for building, repairing, and maintaining the hospital and the houses belonging to it, as well as the foundations and other things related to maintenance.

6) Under a sixth he will note payments for the salaries of our doctors, lawyers, patrons, notaries, and clerks, and for litigation expenses, as well as for documents, writing implements, paper, notebooks, books, and ink used for testaments, codicils, and records of any other kiıd.

7) The seventh heading contains payments for linen and wool clothing for the sick and the members of the hospital household; also payments for leather cloaks and hats and other things relating to clothing and shoes.

${ }^{48}$ I.e., items of personal property received in bequests to the hospital. 


\section{The Ospedale di Santa Maria Nuova}

8) Under the eighth the treasurer will note payments for taxes, gabelles, and tolls levied on persons and on goods inherited by the hospital, as well as those to whom they are paid.

The treasurer may trade, buy, sell, receive, and claim all moveable property pertaining to the needs of the hospital, the house, the family, and the sick. He must do these things subject to the advice and will of its Rector, with one exception: when the treasurer is sick, absent, or unable for some other reason to receive and record payments the Rector can and must do so, and when the treasurer is again available the Rector must quickly consign to him everything he has received and recorded.

[9] The treasurer must account for the property he manages.

Every two months, by the eighth day of the following month, we require the hospital treasurer to present a full and accurate accounting of everything he has received and paid out during those two months. Once his term is over, he must present a general reckoning for his entire term-moneys received and paid out, accounts payable and receivable, and all other things of this kind - to the Rector of the hospital or to his deputy, as well as to one of the senior patrons.

[10] The property of the hospital may not be given away or alienated.

We have ordered that no one may sell, alienate, or give away money or any other thing, property or right belonging to the hospital to any lay brother, perpetual servant, or other member of the hospital household, male or female, either temporarily or permanently. There is one exception: the Rector of the hospital may donate to the poor and sick what money or moveable goods he wishes, in keeping with the hospital's resources, according to God and his own conscience, which we consider the legitimate judge in these things.

\section{[11] The hospital may not take married people into its household.}

No married person, male or female, and no member of a religious order may be accepted into our household or wear its habit, in accordance with the practice of the hospital.

[12] No outsiders may live in the hospital.

In the interests of the hospital we have also decided that neither its Rector nor anyone else may invite outsiders, foreigners, or sick people to stay in the house ${ }^{49}$ for more than three days at a time, except for clerics serving in the hospital church. Nor may they invite any secular or lay persons, except one of the patrons, to attend the feasts of the hospital against the wishes of the governors and patrons; these feasts are the feasts of Sant'Egidio, Santa Lucia, and the Purification of the Virgin.

[13] Everyone living in the hospital must take the sacraments.

We require all members of the hospital's household, male and female, lay brothers, officials and permanent servants, to go to confession at least three times a year and to take communion twice a year, at Christmas and Easter, from a priest either in the hospital or outside it, as directed by the Rector of the hospital. The women of the house receive these sacraments in a holy place from the priest appointed for the purpose.

[14] No one living in the hospital may leave it without permission from the Rector.

No member of the hospital family, male or female, may leave it to walk through the city or may go anywhere in the city of Florence or the surrounding countryside without explicit permission from the Rector of the hospital, and then he may not go alone. Even the Rector, when he has to go into the city, must be accompanied by one of the oldest and most senior members of the household, and he may not spend the night outside it without a legitimate reason, and then only with a companion.

[15] Choosing the sacristan.

The Rector of the hospital chooses a sacristan, someone getting on in years, to look after the church. This man oversees twelve other priests, called chaplains, and six clerics, who conduct

\footnotetext{
49 Note the clear distinction between the "house", where the staff and residents of the hospital lived, and the infirmary and its annexes housing the sick, who could and frequently did stay more than three days.
} 


\section{Katharine Park and John Henderson}

services, as well as their acolytes. He keeps an inventory of everything used in the services and stored in the sacristy and sees that the masses and the seven canonical hours are performed according to Church practice. All of the above receive a salary and compensation for their work, in addition to food, lodging, and the services of a barber. The power to approve or disapprove these priests, that is to hire or discharge them, lies with the Rector of the hospital rather than with the sacristan.

The sacristan sees that on days appointed by the Rector, two masses are celebrated at Prime, ${ }^{50}$ one in the men's church and one in the women's; all members of the household must be there unless incapacitated or absent for legitimate cause. This includes the Rector of the hospital, who should encourage the negligent to attend services, warning and punishing them if they do not. The other priests should perform their rites day and night. The Rector of the hospital chooses two chaplains to hear the confessions of the sick and to give them the sacraments. One of these chaplains stays in the men's infirmary, alternating day and night duties with the other; the other celebrates mass in the hospital chapel so that the sick can hear it, sometimes in the morning and sometimes in the evening and at vespers. The same priest leads confession in a loud voice, so that all the sick can hear, and commends them to God for the night.

[16] How the sick receive the sacraments.

We put up a board in a visible place divided by ruled lines into four sections. In one section we write the names of those patients making confession; in the second we record those about to receive the Eucharist; in the third, those commending their souls to God; and in the fourth, those receiving extreme unction. This board is looked after by the chaplains and priests responsible for the sick.

[17] Foreign priests may be called in.

We take in not only our own countrymen but also foreigners, and whenever sick people from England, Spain, France or Germany come or are brought to the hospital, we pay priests and other people fluent in these languages to come, so that each can receive the sacraments and make known his last wishes in his own tongue.

[18] The Rector of the hospital chooses the infirmarer, who has principal responsibility for the sick.

The Rector of the hospital appoints an infirmarer on his own authority to care for the sick; he is always chosen from among those who have offered themselves in perpetual service to the hospital. The infirmarer has four deputies, also chosen from the perpetual servants, called head nurses [here duces custodiarum et vigiliarum; elsewhere duces custodium et vigilum]. Each oversees seven assistants, men who are serving God and the poor because of a vow or out of piety; these receive their food and clothing from the hospital and may not leave it without the Rector's consent. All wear the hospital's grey habit and its symbol. The head nurses divide the day into six-hour shifts, so that one head nurse and his seven assistants are always on duty in the infirmary to serve the sick. They walk up and down among the patients, ready to run to them and assist them with piety and compassion, should the need arise.

[19] The hospital staff bring townspeople and travellers to the hospital on a litter if they cannot come by themselves.

Recently the Rector of the hospital has adopted the practice of having brought to the hospital [some] of the many pilgrims travelling to and from Rome, as well as sick and poor Florentine citizens and residents. He tells one of the perpetual servants to summon four or six others to carry the litter. The same man takes a small plate of sweets and goes with the others to the place where the sick traveller or townsperson has been reported, and they pick him up and carry him to the hospital. They do this almost every day, which is a great work of piety.

\footnotetext{
${ }^{50}$ Prime is the first canonical hour of the Divine Office, beginning originally at 6 a.m., but often held at sunrise.
} 


\section{The Ospedale di Santa Maria Nuova}

\section{[20] How the sick are received.}

The [men's] hospital has 100 beds, each numbered, so that any patient can be located easily. ${ }^{51}$ These are made up with mattresses, pillows, linens, and covers. In the middle of the infirmary there is a little bed covered with a cloth on which the sick are laid when they first arrive. As soon as they are admitted the infirmarer comes to them to determine the nature of their illnesses. He assigns the feverish and those with skin lesions or wounds to empty beds, in either the upper or the lower place, ${ }^{52}$ and he sends one of the head nurses to wash the sick person's feet and another to the sub-infirmarer to get slippers, a leather robe, a shift, a cap, and two pillows for him. In winter we heat the beds with bedwarmers, cover them with blankets and use caps made of wool; in summer the clothes and caps are made of linen, and we use tunics without sleeves.

\section{[21] The Rector of the hospital chooses a sub-infirmarer.}

Where there are many people and no order things become confused, for we cannot all do everything. Therefore the Rector of the hospital assigns different duties to different servants. He appoints a sub-infirmarer from among the perpetual servants to look after the linens, shifts, underpants, caps, cloaks, tunics, outer garments, pillows of all kinds, towels, sandals, slippers, bedwarmers, bedpans, and crutches - all marked with the hospital's seal. The sub-infirmarer stores the patients' clothing in the following way. Once the sick person has been assigned to a bed, he comes, collects all the clothes taken off by the patient, and wraps them up. He notes his name, father's name, place of origin, family name, and the amount of money he is carrying, if any, and he writes all this on a label attached to the bundle, which he places in a storeroom called the Pergola. Before the bundle is taken away, one of the perpetual servants, who is appointed to this task by the Rector of the hospital, comes and records the patient's name and patronymic in a book, together with his family or nationality, as well as his bed number and whether he is lying in the upper or the lower part. This book is kept in alphabetical order. If the patient should die, there is another book in which the particulars are recorded: when he died, when he left the hospital, and when he arrived. After all this has been recorded, the sub-infirmarer takes the patient's clothes and belongings and puts them in a storeroom or depository set up for this purpose and adjoining the place we call the Pergola. This depository is lined with chests or cupboards identified by the letters of the alphabet, and the bundle is placed in the cupboard corresponding to the patient's initial. Thus when a guest recovers and wishes to leave, it is easy to find his effects once he tells his name. He is given his clothes and takes them to a place called the Apodyterium or dressing room, which we heat by a fire in winter. There he takes off the hospital's clothes, puts on his own, and leaves in good order. Because many of the poor arrive teeming with lice, we separate out their clothes and store them in the same way but in a different place.

For the comfort and convenience of the sick, the Rector of the hospital delegates one of the perpetual servants to go around the infirmary three times a day; he approaches each bed and asks each patient in turn what dried fruit or sweets he would like-pine-nuts, walnuts, or almonds coated with sugar. This man has responsibility for various things pertaining to the sick, including bread, napkins, sweets, and dried fruit. In the interests of hygiene ${ }^{53}$ we keep the

\footnotetext{
51 For the women's infirmary, see rubric 29 below.

52 Aut in parte superiori aut inferiori. The meaning of this phrase is unclear; it could be interpreted as referring to bunk beds, except that such an arrangement seems inconvenient, and all the pictorial evidence from other early Italian hospitals shows double beds. The books of the dead from the early sixteenth century do indicate two places in each bed, abbreviated "k" and "p" (kapo and piedi?). This seems to suggest that the patients lay head to foot in the bed. This otherwise unlikely hypothesis may gain some support from a passage in the regulation of 1652 , which describes the head nurses as attaching a note concerning the patient's treatment "at the sick person's head or at his feet" (a capo dell'Infermo o da piedi); Targioni, op. cit., note 7 above, p. 419.

${ }^{53}$ Hygiene (dieta) was the part of medieval and Renaissance medicine concerned with what were called the six non-naturals: food and drink, air, exercise and rest, sleeping and waking, evacuation and repletion, and the emotions. See note 35 above.
} 


\section{Katharine Park and John Henderson}

hearth in the infirmary constantly lit, stoked not with smoking wood but with a great heap of charcoal; we burn 500 bushels [modia] of coals a year in that fireplace. Above the hearth hangs a copper cauldron, four casks [cadi] or more in volume, full of hot water for use in the infirmary. We use this fire to heat linens and blankets, surgical knives, bricks, compresses, poultices, syrups, medicines, and many other things needed by the sick.

Three doctors, called residents [adstantes], are always in the hospital looking after the sick. In return they receive board and a large and pleasant room worthy of their position. They are young men and, in the course of seeing a wide variety of illnesses and using many different remedies, they become increasingly skilled and expert, since, as they say, experience is the teacher of all things. Together with the infirmarer these junior doctors direct the treatment of the sick, dividing up the beds and the patients. All four report to six other doctors, the best in the city, who receive a salary from the hospital. These six senior doctors come to the hospital each morning at a set time. As he sees each one arrive, the head nurse on duty at the time orders a bell to be rung, and at its sound one of the pharmacist's assistants runs to meet the doctor, bringing a white linen garment with which he covers his clothes; he then accompanies the doctor to the beds. The same bell summons the infirmarer and one of the resident doctors; following the senior doctor from bed to bed among those assigned to them, they explain to him the nature of each patient's illness and its symptoms, his state of mind, and what has been done for him up to that point - syrups, medicines, ointments, massages, plasters, blood-letting, and so forth. The senior doctor then carefully prescribes treatment, which the pharmacist's assistant writes down in a book. Later the medicines are made up for each patient, sparing no expense. When the doctors leave, water is poured for them so that they may wash their hands. Once they have left, the infirmarer goes to the pharmacy to see about the medicines, syrups, and other things ordered by the doctors. The name of the sick person for whom these remedies are prescribed is written on a scrap of paper; the bed number on the paper also serves to identify the flasks or trays used to bring the patient his medication. The pharmacist makes up all the prescriptions and gives them back in order to the infirmarer, who together with the head nurse on duty gives them to the patients for whom they were prepared. If the doctors order compresses, ointments, plasters, or enemas, they are administered by one of the permanent lay brothers entrusted with this work.

In the same hospital there is a separate place called the Medicinarium, where we treat those with sores and other minor illnesses; there are a great many such people in the city and surrounding countryside. We employ a surgeon to treat them, the best in Florence, and he is assisted by three of the lay brothers, who have learned surgery through long experience. Those who are able, come to the doctor; he goes to the others bed by bed, for example to the wounded and those with bad legs. The surgeon must spend two hours in the morning and two in the evening attending the sick. Of the three resident doctors, one or two are always in the hospital to attend immediately to people who are brought in wounded or otherwise ill.

People who cannot afford house calls by a private doctor come to us and receive everything they need. We give ointments to anyone who asks, so that in a single year we use 600 casks of oil to make them up. We also prepare linen cloths soaked with various medications for treating sores, of which we give away 2,500 ells [ulnae] each year. A lay brother collects the used bandages and cloths and brings them to the women's house, where they are washed so that they can be reused, which saves a great deal of money.

In addition, we have built a large and well-equipped office to store the herbs and spices used by our salaried pharmacist to make up medicines and ointments. He has four assistants who work for board alone, as an act of piety. The room has twenty-two vessels for distilling things needed for medicines. Two are used to prepare drop by drop the extract of chicken and capon that we give to the seriously ill both in the hospital and outside it. They are in continual use, and we use eight or ten capons every day in this way. The assistants prepare all the medicines using only the best ingredients. Each year we consume 4,000 pounds of cane sugar and as much again of honey, 2,000 pounds of native wax, 800 pounds of white wax, 2,000 pounds of cassia, 20 pounds of rhubarb, 12 pounds of manna, and other things of this sort. The total cost comes to between 1,500 and 2,000 gold florins. 


\section{The Ospedale di Santa Maria Nuova}

The hospital also has eight rooms with hearths, washbasins, toilets, and other amenities reserved for the sick of higher social class, such as nobles, who have decided to come to us for treatment on account of poverty or a religious vow. We look after them with great care. There is also a place for those with bad wounds or skull fractures; this ward has no windows, because fresh air is very bad for patients of this sort. Two servants are always in attendance there to look after them and answer their calls. We call another place attached to the hospital the Sapientia, where we care for priests and clerics; a bell hangs there with which they can ring for help. We have set apart another place for those who have lost their minds through illness, where they are kept in chains. ${ }^{54}$

When a patient is close to death, we place before him an image of Christ on the cross, and a nurse watches over him, never leaving him and reading him the Creed, the Lord's Passion, and other holy texts. When he is dead, the head nurse comes with his assistants; they take the dead man from the bed, clothe him in linen, and place him on a bier in the middle of the hospital, where the chapel is, with a consecrated candle at his head and a lamp at his feet. At the appointed time a bell rings, and the priests come with a cross. Two lay brothers light two torches, and the others take the body and bear it into the church, where the funeral service is sung. After these rites they go to the cemetery, and the corpse is buried by a servant appointed for the task.

Our servants are completely dedicated to the care of the sick; several are always on call away from the hospital visiting various houses in the city, and many gravely ill people, including nobles and patricians, are entrusted to their care. Let these few words suffice concerning their patience, dedication, and hard work. Everyone knows how dirty, smelly, and disagreeable the sick are; one must accept their importunities with patience. Our nurses take turns in the hospital as described above, running to and fro among the sick as they call. To some they bring hot water, to others an infusion of barley water, to others a julep or sweet drink. They must hold some up, carry others, dress others, restrain others, and to others bring bedpans. Some of the sick cry out, others shiver, others are delirious. But the nurses bear it all and serve with piety and patience.

\section{[22] Distributing the chicken soup.}

Before meals we offer to the seriously ill a soup made from pureed chicken. At the sound of a bell, a servant brings a pot full of this liquid from the women's quarters and places it on a bench in the middle of the hospital, where there is a sink set up containing vessels for drinking and washing hands. The infirmarer comes and ladles the soup into cups with a serving spoon as the servants stand by. The nurses have a brass basin that holds a napkin and two cups. One contains water flavoured with lemon, damson or another such fruit. The nurse uses the other cup to carry soup to the beds. The sick person drinks it, washes his mouth with the water, wipes it with the napkin, and the nurse leaves him.

\section{[23] The organization of meals.}

At dinner-time a servant takes the loaves of bread and cuts them into many pieces. Other attendants bring two napkins to each patients. The sick person spreads one napkin on a board rather like a table, which is kept at the head of his bed, and he uses the other to keep himself clean. The attendants bring water to each patient to wash his hands, cold in summer and hot in winter, and towels to dry them. Another nurse hands out pieces of bread and continues to distribute them throughout the meal to anyone who wants more.

Meanwhile the infirmarer orders a bell to be rung once, and then, after an interval, again. Between these two signals, trays are brought to a place called the Distributorium, where there are all sorts of wooden dishes and other utensils. There a table is spread, presided over by the

\footnotetext{
54 This provision excludes that small proportion of the mentally ill considered to have lost their minds through supernatural causes (divine judgement or daemonic possession) and who would therefore have required spiritual rather than physical treatment. Cf. the description for King Ferdinand, which specifies that only the violent, who pose a threat to themselves or others, be sequestered in this way; Passerini, op. cit., note 7 above, p. 868 .
} 


\section{Katharine Park and John Henderson}

infirmarer and two of the head nurses on duty at the time. They make up trays of food for each sick person, which are handed out by the servants and others in attendance. These carry the food to each patient as the infirmarer calls out his name and bed number. The people who do this include not only all the servants who are not otherwise occupied, but also all the guests of the hospital, both Florentine and foreign, who take off their outer robes for the purpose. In winter they bring each patient glowing coals in an earthen vessel so that he may warm his hands to eat. While the sick are eating, three servants go around the ward serving excellent wine. Each sick person receives an appropriate amount of the particular wine - white, red, smooth, sweet, or dry-suited to his illness and his appetite. All this is done in silence.

After the meal, everything is put away, and the dirty dishes and other wood and pottery utensils are brought to the Distributorium, where they are cleaned by a lay brother. The leftover pieces of bread are thrown in a cradle and distributed to beggars at the hospital gate by the same lay brother who cut them up. Note that during the meal one of the head nurses circulates among the patients with his seven assistants. If they see that some of the sick are too weak to eat they lift them up, prop them up with pillows, feed them, comfort them, and encourage them. At the end of the meal the infirmarer and the sub-infirmarer note which of the sick have not eaten and have a second meal prepared for them of lighter foods. We do the same thing in the evening, at supper, and follow all of the same procedures. Meanwhile the sub-infirmarer and the head nurse on duty smooth the beds and order dirty sheets to be changed. During this process those patients who are able get out of bed; if they cannot, we straighten their beds as well as we can.

We require that the Rector of the hospital and all the lay brothers, servants, officials, and other members of the hospital come to table together in their respective refectories, male or female, and eat the same food at the appointed times; no exceptions are made unless someone is obviously ill. Furthermore, they are required to observe all fasts and vigils and Advent, like other clerics. ${ }^{55}$ They eat in silence to the reading of some religious text, except on the feast-days of either the church or the hospital. And if there are guests from outside, let another person take charge of the readings at table.

The Rector of the hospital appoints a steward and under-steward, called Castaldi, from among the perpetual servants; they keep the keys to the wine and the bread and oversee the lunches and suppers of the healthy.

The refectory is large and contains five tables, one at the head and the others on the right and the left. The Rector of the hospital and the priest sit at the head table; the perpetual servants at the first, on the right; those responsible for the hospital's food and clothing at the second, on the left. The rest sit at the other tables in no special order. One person looks after the refectory, washing the floor, laying the tables, handing out the cups, and bringing the dirty napkins to the women of the hospital each day. At mealtimes, the steward and under-steward go to the women's residence for the various dishes for the healthy, which are carried in their own pots in special baskets to a small room behind the refectory. Wine is drawn from the containers where it is kept. Then the various dishes are passed out to each diner through a window, and he takes his place at table at the sound of a bell rung once and then again. Grace is sung, and everyone sits down, while a cleric mounts to a lectern and reads. The steward divides up the portions and the food and wine are passed out by two assistants. No food may be taken from the refectory except by special permission or request. Once the meal is over, the Rector of the hospital gives a signal, and those present rise and go into the church to give thanks. On Sunday the Rector urges everyone to perform his duties and rebukes those who need it.

Because not everyone can eat at the same time, we plan for two lunches and two suppers. At the end of the meal, one of the head nurses with his assistants - alternating by weeks - takes responsibility for washing the dirty dishes; they clean these in boiling water carried from the women's residence, and bring them back to the steward. Next to the room in which the food is

\footnotetext{
${ }^{55}$ An agreement in 1425 submitted the residents of the hospital to the same religious discipline as the Augustinian canons: SMN-10, f. 28v.
} 


\section{The Ospedale di Santa Maria Nuova}

set out is a place called the guesthouse or Hospitalium, where the muleteers eat when they cannot observe the bell, as well as the overseers of the hospital's estates and pilgrims who are guests of the hospital. This is the steward's responsibility. In winter we also use this room to feed the head nurse and other nurses on duty in the ward during the first part of the night, through the sixth hour. The steward also looks after the linens and linen clothing of the healthy; they hand in their dirty laundry, and he returns it to them on Sunday, after the women have washed it by boiling it. The steward or under-steward also sees to the wine cellar. He stores wine of every kind separately: sweet, smooth, dry, white, and red-five or six thousand casks a year.

[24] Only those who die in the hospital may be buried in the hospital church or cemetery.

Neither the Rector nor anyone else living in the hospital may give permission for the body of someone who has not died in the hospital to be buried in its cemetery, church, or elsewhere in its jurisdiction, without the express licence of the governors and patrons. The latter may, however, give permission for this, for the prohibition does not apply to them or the members of their households.

[25] Nowhere in the hospital may any shrine or chapel or other construction be marked with the insignia of any person.

We have decreed that neither the Rector nor anyone else living in the house may give permission, either directly or indirectly, for any person, organization, guild, or corporation to install any object in the church, chapel, cemetery, or any other place in the hospital - whether a building, painting, sculpture or other such work, or an altar, oratory, tomb, monument, standard, or inscription - without the express permission of the governors and patrons of the hospital. Excepted from this are images of holy people and saints for decoration and devotion, but they must carry no arms or insignia of any individual or family.

[26] No one may divulge the affairs of the hospital.

We have further decreed that without permission of the patrons and governors, no member of our house may reveal or divulge to any outsider either directly, indirectly, tacitly or explicitly, any matter or affair relating to the hospital that could bring harm, prejudice, disgrace, or dishonour to it or any of its patrons or any of our household, under pain of severe punishment by the Rector of the hospital. The only persons excepted from hearing such things are the archbishop or his vicar. The Rector must recall this prohibition often and rebuke and punish offenders as he sees fit.

The Rector is responsible for warning, rebuking, or punishing any person subject to the hospital who has broken one of the provisions detailed above and below, or who has committed any other fault or misdeed, and he may determine the penalty for any such misdeed if it is not already specified in these statutes and regulations, with one exception: he may not expel any household member, servant, or lay brother from the hospital community without the consent and authorization of the household, the lay brothers, and the officers of the house, or of the majority of them, particularly the older ones.

\section{[27] The oath and observation of these chapters.}

We have decreed that within eight days after being named and confirmed and after being informed of the rules and regulations contained here, each Rector of the hospital must solemnly swear that he will observe them and ensure to the best of his ability that they are observed by everyone associated with the hospital, under pain of losing every right and privilege of the house - the penalty they will incur immediately after the infraction. Similarly, each member of the household swears and promises to do the same. If he does not he is punished in the following way. On the first offence, he must sit on the floor in the middle of the refectory and eat bread and water for three meals while the others look on and eat at table. On the second intentional offence, he must eat seven times in this way. On the third offence, he must be deprived of every office, benefice, service, function, and honour of the hospital, without respect to age or status, according to the judgement of the Rector of the hospital. No one punished in this way may be restored to his original position without the consent of the 


\section{Katharine Park and John Henderson}

Rector, four of the lay brothers, the servants, and the governors and patrons of the hospital - with one exception: absolution for perjury is reserved to the archbishop or his vicar.

For the profit of the house we have placed boxes for daily alms and personal donations in front of both the men's and the women's hospitals. They are locked with three keys, one kept by the Rector of the hospital, one by the treasurer, and one by the sacristan or the oldest and most trustworthy of the lay brothers. These men open the boxes four times a year; the treasurer counts the contents and records them in his daybook, that is the book in which he registers goods received.

\section{[28] Hiring the notary.}

We have found it useful to hire a notary with a good knowledge of the law to represent the hospital in legal matters. He receives a salary and is chosen by the Rector and the lay brothers for whatever term they wish. His duties are the following: to summarize and record testaments, draw up wills, and take care of all bequests, leases, contracts, and legal instruments and records relating to the hospital.

[29] An inventory is made when the office of the Rector falls vacant.

We have decided that when the Rectorship of the hospital falls vacant, the patrons and governors then present in the city, or a good part of them, should meet with the lay brothers-or failing that, with four of the older members of the household-and have an inventory drawn up of all the books, vessels, vestments, treasure, furnishings, goods, and other things belonging to the hospital, which must all be carefully looked after. Once a new Rector has been appointed, these things are reported to the treasurer and the sacristan.

We have set these things out concerning the administration of the men's house as neatly and briefly as possible. The same things apply to the women's house, with some modifications. A hundred women live in the women's part of the hospital, perpetual servants and assistants, humbly clothed like the men. They have been admitted by the Rector of the hospital, and they look after the sick and the well in the following ways.

First, they receive sick women in their hospital and care for them as described above. The Rector of the hospital appoints a female infirmarer and nurses, with exactly the same responsibilities as in the men's hospital. The women include several skilled in surgery, for experience is the mistress of all things. ${ }^{56}$ These have many remarkable cures to their credit and are even more trusted than the men. About ten women are responsible for making the bread for the sick and the well of both sexes. Employees of the baker located next to the hospital take the loaves and return them baked, bringing as many as are needed to each house. The women change duties each week, replacing each other in a fixed order. Ten take care of the cooking and prepare the food. Fifteen do the laundry, scalding, cleaning, washing, drying, and folding it each day. Eight look after the chickens, hens, geese and ducks, of which there are incidentally 1,000 . For the hospital consumes 20,000 chickens each year and as many eggs. The Rector of the hospital appoints one woman to keep the linen clothes, another the woollens, and another the bed linens, the napkins, and the cloths. Another looks after the room containing the sacred objects.

The women's quarters and hospital are closed each night at dusk, and the key taken by one of the lay brothers. If a female patient needs the sacraments, they call for a priest by ringing a bell. If a sick woman is brought to the hospital during the night for a legitimate reason, the hospital is opened to receive her. They ring the bell once if a patient wants the sacraments, twice if she wants communion, and three times if she needs extreme unction.

[30] How the Rector of the hospital looks after the women.

The sacristan of our church and an elderly priest of blameless life and irreproachable habits hear the women's confessions and administer them the sacraments both day and night. Two of

56 “. . magistra rerum experientia": In other words, these women were empirically trained surgeons who had learned their craft through apprenticeship and experience, presumably in the hospital, rather than through a formal course of study. 


\section{The Ospedale di Santa Maria Nuova}

the older male servants attend them when they do so, opening and closing the women's hospital for them but remaining in the vestibule. They do not allow men to enter unless they are visiting patients [nisi infirmas intus habeant], and one of them accompanies male visitors at all times until they have left the hospital. Female visitors may come and go freely. These men have other responsibilities, and through them the women ask for bread, wine, oil, salt, and firewood when they need it. They report these requests to the Rector of the hospital or the treasurer. Another four male servants perform additional duties of this sort.

Two large jars stand at the entrance of the hospital, one containing boiled [water] and the other, oriza, or barley water. Anyone in the city may request them for the use of the sick, and we dispense ten casks of each daily.

\section{[31] No one may enter the women's quarters.}

We have decided in addition that no Rector of the hospital, present or future, and no Rector, officer, lay brother, or member of the male household may enter or stay in the women's hospital and in the places where the women work and live, without a legitimate and honourable reason, and even then he must be accompanied by another member of the household.

\section{[32] The Rector of the hospital visits the women once a month.}

The Rector of the hospital must visit the women's hospital once a month, especially on feast days, in order to encourage, warn, admonish and console them, and to maintain peace and harmony, root out scandals, and mediate quarrels - keeping in mind the nature and weakness of the female sex-so that the women remain busy and diligent, cultivating and observing charity, piety, and patience.

\section{[33] No meeting is to be called or compact made against the governors of the hospital.}

Under no circumstances may the Rector presume to call any meeting or gather together the members of our household and its employees in order to impeach the honour and authority of the governors and patrons of the hospital or to prejudice any of their rights.

\section{[34] How these statutes are to be kept.}

We have decided in the general interest that these statutes concerning the Rector of the hospital and the rest be written down in two books, of which one will be public and kept in a suitable place, secured by a chain, and the other locked in an alms-box. All provisions must be observed piously, carefully and diligently, under pain of the penalties contained in themsaving always and in all things the authority and power of the archbishop or his vicar, and their successors, to add to, delete from, change, and rewrite them as they wish.

At the end of this work we append a number of things relevant to the hospital's expenses:

The hospital has a garden kept by three gardeners; we take our vegetables from here, and if we need more we buy them in the public vegetable market, spending some 100 florins a year in this way.

The six muleteers keep twenty mules, which are used to carry things to the hospital from its farms and fields. The cost is 300 florins.

We hire an agent to visit the various estates of the hospital, to administer them, and to keep their records and manage their contracts.

We assign to various places lifetime agents, who are married but who have made over their property to the hospital, to various places in order to look after many of our farms. These are chosen for their trustworthiness, for they cannot always give an accounting of their revenues.

We have a butcher to manage the hospital's slaughterhouse, for we raise sheep, lambs, pigs and calves. Each month we slaughter 1,200 rams, 700 lambs, 500 young goats, 400 calves, and 100 pigs. The expense comes to 1,800 florins or more.

Our shoemaker cuts out and sews shoes for everyone in the hospital, sick and well.

We hire a miller to grind our grain, for we use 360 bushels a year.

Each Thursday, four barbers come to the hospital to shave and cut the hair of its residents. The hospital pays for all of these things. 
To the same most serene king of England:

These are the works of our city and our hospital, most glorious king, and the things, outstanding for their great piety and remarkable charity, that we have taken pains to convey to you, dividing them up and setting them forth according to our own wit and ability. But your crown by its eminence and its clemency will stand greater and more pious by far-rather as the greatest and most pious, according you praise, glory and eternal life. As Pliny the Younger has said, both wisely and truly, "Seeing that we are not permitted to live long, let us leave something by which we bear witness that we have lived". We pray for only one thing: that you will place us - by our own merits the least of your majesty's servants-not unwillingly but with a smiling visage under the protection of your crown. Live happy and forever, O King. 